\title{
PERBAIKAN KUALITAS BAHAN PEMBAWA RHIZOBIUM DAN FUNGI PELARUT FOSFAT MELALUI STERILISASI SINAR GAMMA Co-60 DAN PENGARUHNYA TERHADAP PERTUMBUHAN DAN PRODUKSI KEDELAI (GLYCINE MAX L.)
}

\section{CARRIERS QUALITY IMPROVEMENT OF RHIZOBIUM AND PHOSPHATE SOLUBILIZER FUNGI THROUGH CO-60 GAMMA-RAY STERILIZATION AND ITS EFFECT ON THE GROWTH AND PRODUCTION OF SOYBEAN (GLYCINE MAX L.)}

Taufiq Bachtiar', Iswandi Anas ${ }^{1}$, Atang Sutandi'1, dan Ishak ${ }^{2}$

${ }^{1}$ Departemen IImu Tanah dan Sumber Daya Lahan - Institut Pertanian Bogor, Jl. Raya Dramaga Babakan, Bogor, 16680 ${ }^{2}$ Pusat Aplikasi Isotop dan Radiasi - Badan Tenaga Nuklir Nasional, JI. Lebak Bulus Raya No. 49, Jakarta Selatan, 12440 E-mail: taufiqb@batan.go.id

Diterima 7 Juli 2018, diterima dalam bentuk perbaikan 18 Oktober 2018, disetujui 13 Pebruari 2019

\section{ABSTRAK}

\begin{abstract}
PERBAIKAN KUALITAS BAHAN PEMBAWA RHIZOBIUM dan FUNGI PELARUT FOSFAT MELALUI STERILISASI SINAR GAMMA Co-60 DAN PENGARUHNYA TERHADAP PERTUMBUHAN DAN PRODUKSI KEDELAI. Varietas unggul kedelai yang dihasilkan dari teknik mutasi radiasi harus didukung oleh teknologi pertanian seperti penggunaan pupuk hayati. Penelitian ini dilakukan untuk mempelajari pengaruh iradiasi gamma Co-60 terhadap 1) sifat kimia bahan pembawa, 2) viabilitas mikrob dalam bahan pembawa, 3) pertumbuhan dan produksi kedelai varietas Mutiara 3. Komposisi bahan pembawa yang diuji meliputi $b_{0}=100 \%$ gambut $(\% w / w), b_{1}=50 \%$ gambut $+50 \%$ biochar $(\%$ w $/ w), b_{2}=50 \%$ gambut $+50 \%$ fosfat alam (\% w/w), $b_{3}=50 \%$ gambut $+25 \%$ biochar $+25 \%$ fosfat alam ( $\%$ w/w), b4 $=100 \%$ biochar ( $\%$ w/w). Metode sterilisasi yang digunakan yaitu dengan iradiasi sinar gamma Co-60 (r) dan autoclave (a). Hasil menunjukkan komposisi bahan pembawa dan sterilisasi sinar gamma berpengaruh terhadap sifat kimia bahan pembawa yaitu $\mathrm{pH}, \mathrm{NO}_{3}$, dan $\mathrm{P}$ tersedia. Viabilitas Rhizobium $\mathrm{R} 35$ dan fungi pelarut fosfat FPF4 dengan jumlah populasi tertinggi diperoleh pada bahan pembawa biochar dengan sterilisasi iradiasi sinar gamma. Penggunaan pupuk hayati dengan bahan pembawa biochar yang disterilisasi dengan iradiasi sinar gamma Co-60 berpengaruh nyata dalam meningkatkan serapan $N$ dan serapan $P$ pada biji, dan hasil tanaman kedelai varietas Mutiara 3.
\end{abstract}

Kata kunci: sterilisasi, iradiasi, sinar gamma, kedelai, pupuk hayati

\section{ABSTRACT}

CARRIERS QUALITY IMPROVEMENT OF RHIZOBIUM AND PHOSPHATE SOLUBILIZER FUNGI THROUGH CO-60 GAMMA-RAY STERILIZATION AND ITS EFFECT ON THE GROWTH AND PRODUCTION OF SOYBEAN. The new soybean varieties were produced by mutation breeding technique should be supported by agricultural technologies such as biofertilizer. This study was aimed to study the effect of Co-60 gamma rays sterilization on 1) chemical characteristics of biofertilizer carriers 2) microbes viability in carrier materials 3) production of Mutiara 3 soybean variety. The carriers composition were tested consist of $b_{0}=100 \%$ peat $(\% w / w), b_{1}=50 \%$ peat $+50 \%$ biochar $(\% w / w), b_{2}=50 \%$ peat $+50 \%$ rock phosphate $(\% \mathrm{w} / \mathrm{w}), b_{3}=50 \%$ peat $+25 \%$ biochar $+25 \%$ rock phosphate $(\% \mathrm{w} / \mathrm{w}), b_{4}=100 \%$ biochar $(\%$ $w / w)$. The sterilization methods were used in this study consist of gamma rays irradiation Co-60 ( $r$ ) and autoclave (a). The results showed that the carrier composition and the gamma rays sterilization method gave significant effect on $\mathrm{pH}$, available $\mathrm{NO}_{3}$, and available $\mathrm{P}$. Biochar with $\mathrm{Co}-60$ gamma ray irradiation gave the highest population number of Rhizobium and FPF4 phosphate solubilizing fungi. Biofertilizer consist of biochar carrier material with Co-60 gamma irradiation gave significant effect on $N$ uptake and $P$ uptake in seeds, and soybean yield of Mutiara 3 variety.

Keywords:sterilization, irradiation, gamma rays, soybean, biofertilizer 


\section{PENDAHULUAN}

Droduksi kedelai (Glycine max L.) di Indonesia masih tergolong rendah dengan rata-rata produktivits 1.5 ton/ha per tahun. Produktivitas kedelai Indonesia pada tahun 2016 turun 2,90\% dibandingkan dengan tahun sebelumnya [1]. Nilai produktivitas ini jauh lebih rendah bila dibandingkan dengan penghasil utama kedelai Amerika Serikat yang memiliki produktivitas sebesar 3-4 ton/ha per tahun [2]. Rendahnya produktivitas dapat dikarenakan pada daerah tropis sebagian besar tanahnya memiliki kesuburan yang relatif rendah.Teknologi yang tepat dapat meningkatkan produksi kedelai (Glycine max L.) di Indonesia. Berbagai varietas kedelai unggul nasional telah dihasilkan, salah satunya adalah varietas Mutiara 3 yang dihasilkan Badan Tenaga Nuklir Nasional (BATAN). Varietas unggul ini harus didukung teknologi untuk memperbaiki sifat-sifat tanah seperti melalui pengapuran [3], pemupukan [4], pemberian bahan organik [5], dan penggunaan pupuk hayati [6]. Aplikasi pupuk hayati Rhizobium pada tanaman kedelai dapat meningkatkan pertumbuhan tanaman, nodulasi, dan serapan nutrisi tanaman [7]. Selain N, tanaman kedelai juga responsif terhadap pemupukan fosfor (P). Cassman et al. [8] menemukan bahwa $\mathrm{P}$ lebih diperlukan untuk pertumbuhan daripada N. Pendekatan bioteknologi melalui bioformulasi dapat menjadi solusi berkelanjutan dan ramah lingkungan dalam meningkatkan produksi tanaman [9].

Batuan fosfat dapat digunakan sebagai sumber $\mathrm{P}$, tetapi memiliki tingkat kelarutan $\mathrm{P}$ yang rendah. Karena batuan fosfat alam tingkat kelarutan $\mathrm{P}$ rendah, sehingga sering tidak meningkatkan produksi kedelai. Penggunaan batuan fosfat alam memerlukan teknologi tambahan seperti penambahan mikrob pelarut fosfat yang terbukti dapat meningkatkan kelarutan $\mathrm{P}$ [10]. Pupuk hayati yang berkualitas selain terdiri dari strain mikroorganisme efektif juga ditentukan oleh bahan pembawa. Bahan pembawa harus memberikan lingkungan aman untuk mikrob selama penyimpanan, mempertahankan kelangsungan hidup mikrob, dan meningkatkan kinerja mikrob ketika diaplikasikan pada tanah [11]. Populasi mikrob dapat menurun secara cepat selama masa penyimpanan dikarenakan bahan pembawa yang tidak cocok [12] dan pengaruh dari bahan pembawa terhadap mikrob. Pada umumnya gambut digunakan sebagai bahan pembawa untuk mikrob fungsional, namun perlu dicari alternatif bahan pembawa yang lain baik sebagai bahan utama atau sebagai bahan substitusi sehingga dapat disesuaikan dengan kondisi daerah untuk produksi pupuk hayati. Selain gambut bahan pembawa yang dapat digunakan adalah arang sekam [13], vermicompost dan lignite [14], kompos dan perlite [15, 16]. Biochar dapat memfasilitasi pengembangan banyak produk bioteknologi yang berbeda untuk pertanian, termasuk pupuk hayati, atau komponen bahan inokulan untuk remediasi tanah terkontaminasi [17].

Penggunaan biochar sebagai salah satu komponen dalam bahan pembawa menarik untuk dikaji, mengingat setiap mikrob menghendaki karakteristik bahan pembawa yang berbeda. Selain itu biochar dapat memperbaiki sifat biologi tanah melalui peningkatan keragaman mikrob [18]. Komposisi bahan pembawa yang tepat diharapkan akan mempertahankan populasi mikrob dalam bahan pembawa dan membantu dalam meningkatkan pertumbuhan tanaman kedelai. Sterilisasi diperlukan untuk mengurangi kompetisi mikrob indigenus dengan mikrob yang ditambahkan ke dalam bahan pembawa. Umumnya autoclave digunakan untuk sterilisasi bahan pembawa. Namun metode ini dapat merubah karakter kimia dan fisik bahan pembawa yang pada akhirnya akan berpengaruh pada populasi mikrob di dalamnya. Iradiasi sinar gamma Co-60 lebih mudah, dapat digunakan dalam skala besar, dan dapat memperpanjang masa simpan $[19,20]$. Tujuan penelitian ini adalah untuk mempelajari pengaruh sterilisasi menggunakan sinar gamma Co-60 dan autoclave terhadap sifatsifat bahan pembawa, populasi mikrob fungsional, dan pengaruhnya terhadap pertumbuhan dan produksi kedelai varietas Mutiara 3.

\section{METODOLOGI}

Isolat Rhizobium yang digunakan dalam penelitian merupakan isolat koleksi dari Laboratorium Bioteknologi Tanah dan Lingkungan IPB Bogor. Isolat R35 telah diuji terlebih dahulu kemampuannya dalam meningkatkan serapan $\mathrm{N}$ tanaman kedelai Mutiara 3 (66,83 mg N/pot) sebesar 25,88\% dari kontrol. Fungi pelarut fosfat yang akan digunakan dalam percobaan juga telah diuji kemampuan dalam melarutkan fosfat pada media 
cair Pikovskaya (285.85 ppm $\mathrm{P}_{2} \mathrm{O}_{5}$ ). Pengujian kompatibilitas dilakukan pada media Yeast Extract Mannitol Agar (YEMA) dan Potato Dextrose Agar (PDA) untuk melihat kompatibilitas masing-masing mikrob. Media YEMA dan PDA yang telah dibuat masing-masing dicairkan dengan cara dipanaskan. Setelah suhu mencapai $\pm 45{ }^{\circ} \mathrm{C}$, media yang masih dalam keadaan cair dituangkan ke dalam setiap cawan petri dan ditunggu hingga membeku. Setelah media membeku kemudian dimasukkan kertas cakram diameter $0,8 \mathrm{~cm}$ (yang sebelumnya telah direndam dalam suspensi mikrob dengan kerapatan masing-masing $10^{7} \mathrm{spk} / \mathrm{ml}$ ) dimasukan ke dalam media tersebut, lalu diinkubasi di dalam inkubator pada suhu $\pm 30^{\circ} \mathrm{C}$. Pengamatan dilakukan pada $5 \mathrm{HSI}$ (hari setelah inokulasi) dengan parameter yang diamati adalah diameter pertumbuhan bakteri dan fungi $(\mathrm{cm})$ serta reaksi antar mikrob. Kompatibilitas ditentukan berdasarkan indeks kompatibilitas (IK) dengan rumus modifikasi Hanudin et al. [21] dan Hamilton \& Attia [22]:

di mana :

$$
\mathbb{I K}=\frac{\text { Pertumbuhan mikrob tunggal }}{\text { Pertumbuhan mikrob gabungan }}
$$

IK $\leq 1$ = campuran mikrob kompatibel

IK $>1$ = campuran mikrob tidak kompatibel

Bahan utama yang digunakan dalam penelitian ini adalah bahan pembawa gambut Rawa Pening. Sterilisasi bahan menggunakan metode sterilisasi iradiasi dengan sinar gamma dengan dosis $30 \mathrm{kGy}$ dan autoclave. Bahan pembawa gambut asal Rawa Pening dikomposisikan dengan fosfat alam asal Blora dan biochar sesuai perlakuan. Sekam padi yang telah ditimbang dimasukan ke dalam wadah keramik bertutup kemudian dimasukan ke dalam furnace dengan suhu $350^{\circ} \mathrm{C}$ selama 45 menit [23]. Biochar yang telah terbentuk kemudian dihancurkan dan dihaluskan. Bahan lainnya yang digunakan sebagai campuran pada bahan pembawa adalah fosfat alam asal Blora. Seluruh bahan pembawa sebelum disterilisasi dikering-anginkan selama 7 hari, dan dilakukan analisis kadar air awal. Bahan pembawa disaring menggunakan saringan ukuran 18 mesh, dan dicampurkan sesuai dengan perlakuan. Bahan pembawa yang sudah dicampur merata dimasukkan dalam kantong plastik High Density Polyethylene (HDPE) dengan ukuran tiap bungkusnya $50 \mathrm{~g}$. Kantong plastik ditutup rapat dengan menggunakan sealer dan disusun dalam amplop. Bahan pembawa kemudian disterilisasi sesuai perlakuan dengan cara menggunakan autoclave (a) selama $2 \times 60$ menit dan diradiasi dengan sinar gamma pada dosis 30 kGy (r). Penelitian ini menggunakan Rancangan Acak Lengkap (RAL) yang tersusun dari 10 perlakuan yang meliputi :

$$
\begin{aligned}
& \mathrm{b}_{0} \mathrm{a}=100 \% \text { Gambut }+ \text { autoclave } \\
& b_{0} r=100 \% \text { Gambut + iradiasi } 30 \mathrm{kGy} \\
& b_{1} a=50 \% \text { Gambut }+50 \% \text { Biochar }(\% \text { w/w })+\text { autoclave } \\
& b_{1} r=50 \% \text { Gambut }+50 \% \text { Biochar (\% w/w) + iradiasi } 30 \text { kGy } \\
& b_{2} a=50 \% \text { Gambut }+50 \% \text { Fosfat Alam (\% w/w) + autoclave } \\
& \mathrm{b}_{2} \mathrm{r}=50 \% \text { Gambut }+50 \% \text { Fosfat Alam (\% w/w) + iradiasi } 30 \mathrm{kGy} \\
& b_{3} a=50 \% \text { Gambut }+25 \% \text { Biochar }+25 \% \text { Fosfat Alam }(\% \mathrm{w} / \mathrm{w})+\text { autoclave } \\
& b_{3} r=50 \% \text { Gambut }+25 \% \text { Biochar }+25 \% \text { Fosfat Alam (\% w/w) + iradiasi } 30 \mathrm{kGy} \\
& b_{4} a=100 \% \text { Biochar + autoclave } \\
& b_{4} r=100 \% \text { Biochar+iradiasi } 30 \mathrm{kGy}
\end{aligned}
$$

Karakteristik bahan pembawa yang telah diiradiasi diamati: $\mathrm{pH}$ dengan metode $\mathrm{pH}$ glass meter, $\mathrm{P}$ tersedia dengan metode biru molibdate, nitrat tersedia dengan metode Ultra Violet [24]. Setiap perlakuan diulang sebanyak 3 kali, sehingga total satuan percobaan berjumlah 30. Analisis data dilakukan dengan menggunakan metode sidik ragam dan apabila berpengaruh nyata dilanjutkan dengan uji beda nilai tengah Duncan Multiple Range Test (DMRT) pada taraf 5\%. Pengujian lama penyimpanan untuk melihat jumlah koloni mikrob total yang diamati selama 3 bulan masa penyimpanan setiap bulannya dengan metode Total Plate Count (TPC). Produksi inokulan, kultur murni dari agar miring yaitu Rhizobium isolat R35 diperbanyak dengan menggunakan media cair 
yeast extract mannito (YEM), sedangkan untuk mikroba pelarut fosfat dengan media cair Potato Dextrose (PD). Sebanyak $10 \mathrm{ml}$ inokulan Rhizobium isolat R35 dalam media cair YEM $\left(2,54 \times 10^{10} \mathrm{spk} / \mathrm{ml}\right)$ disuntikkan ke dalam $50 \mathrm{~g}$ media bahan pembawa, sehingga jumlah awal mikrob Rhizobium R35 yang diharapkan dalam bahan pembawa adalah $5,08 \times 10^{9} \mathrm{spk} / \mathrm{g}$ media bahan pembawa. Selanjutya sebanyak $10 \mathrm{ml}$ fungi pelarut fosfat FPF4 dalam media cair PD (4,5 × $\left.10^{7} \mathrm{spora} / \mathrm{ml}\right)$ sehingga diharapkan jumlah spora mencapai $9,0 \times 10^{6} \mathrm{spora} / \mathrm{g}$ bahan pembawa. Bahan pembawa yang sudah dianalisis dan sudah diinokulasi oleh mikrob Rhizobium R35 dan fungi pelarut fosfat FPF4 kemudian diujicobakan pada tanaman kedelai kedelai vareitas Mutiara 3. Rancangan percobaan yang digunakan dalam penelitian pot ini adalah Rancangan Acak Lengkap dengan 23 perlakuan. Setiap perlakuan diulang sebanyak 4 kali sehingga total berjumlah 92 satuan percobaan. Perlakuan yang dirancang sebagai berikut :

$$
\begin{aligned}
& b_{0} a=b_{0} a+\text { Rhizobium isolat R35 + mikrob pelarut fosfat isolat FPF } 4 \\
& b_{0} r=b_{0} r+\text { Rhizobium isolat R35 + mikrob pelarut fosfat isolat FPF } 4 \\
& b_{1} a=b_{1} r+\text { Rhizobium isolat R35 + mikrob pelarut fosfat isolat FPF } 4 \\
& b_{1} r=b_{1} r+\text { Rhizobium isolat R35 + mikrob pelarut fosfat isolat FPF } 4 \\
& b_{2} a=b_{2} a+\text { Rhizobium isolat R35 + mikrob pelarut fosfat isolat FPF } 4 \\
& b_{2} r=b_{2} r+\text { Rhizobium isolat R35 + mikrob pelarut fosfat isolat FPF } 4 \\
& b_{3} a=b_{3} a+\text { Rhizobium isolat } R 35+\text { mikrob pelarut fosfat isolat FPF } 4 \\
& b_{3} r=b_{3} r+\text { Rhizobium isolat R35 + mikrob pelarut fosfat isolat FPF } 4 \\
& b_{4} a=b_{4} a+\text { Rhizobium isolat R35 + mikrob pelarut fosfat isolat FPF } 4 \\
& b_{4} r=b_{4} r+\text { Rhizobium isolat R35 + mikrob pelarut fosfat isolat FPF } 4 \\
& b_{0} a+50 \%=b_{0} a+\text { Rhizobium R35 + FPF } 4+50 \% \text { NPK rekomendasi } \\
& b_{0} r+50 \%=b_{0} r+\text { Rhizobium R35 + FPF } 4+50 \% \text { NPK rekomendasi } \\
& b_{1} a+50 \%=b_{1} a+\text { Rhizobium R35 + FPF } 4+50 \% \text { NPK rekomendasi } \\
& b_{1} r+50 \%=b_{1} r+\text { Rhizobium R35 + FPF } 4+50 \% \text { NPK rekomendasi } \\
& b_{2} a+50 \%=b_{2} a+\text { Rhizobium R35 + FPF } 4+50 \% \text { NPK rekomendasi } \\
& b_{2} r+50 \%=b_{2} r+\text { Rhizobium R35 + FPF } 4+50 \% \text { NPK rekomendasi } \\
& b_{3} a+50 \%=b_{3} a+\text { Rhizobium R35 + FPF } 4+50 \% \text { NPK rekomendasi } \\
& b_{3} r+50 \%=b_{3} r+\text { Rhizobium R35 } \text { FPF } 4+50 \% \text { NPK rekomendasi } \\
& b_{4} a+50 \%=b_{4} a+\text { Rhizobium R35 }+ \text { FPF } 4+50 \% \text { NPK rekomendasi } \\
& b_{4} r+50 \%=b_{4} r+\text { Rhizobium R35 + FPF } 4+50 \% \text { NPK rekomendasi } \\
& 50 \%=50 \% \text { pupuk NPK rekomendasi } \\
& 100 \%=100 \% \text { pupuk NPK rekomendasi } \\
& \text { kontrol= tanpa pupuk hayati dan pupuk kimia }
\end{aligned}
$$

Tanah yang akan digunakan untuk media tanam adalah Latosol asal Pasar Jumat dengan kedalaman 0 - $20 \mathrm{~cm}$, tanah diambil secara komposit. Tanah dikeringudarakan dan diayak dengan saringan $2 \mathrm{~mm}$. Tanah dimasukkan ke dalam pot dengan berat tanah dalam masing-masing pot adalah $5 \mathrm{~kg}$ tanah Bobot Kering Mutlak (BKM). Pemberian pupuk dasar dilakukan bersamaan dengan penanaman benih kedelai. Biji kedelai yang ditanam memiliki daya kecambah lebih dari $96 \%$. Sebelum ditanam biji kedelai permukaannya disterilkan dengan etanol $70 \%$ dan dibilas dengan air suling steril [25]. Inokulasi dilakukan sesuai perlakuan modifikasi Hartley [26] dengan memberi $0,3 \mathrm{~g}$ inokulan untuk $4 \mathrm{~g}$ biji yang dicampur air steril. Penanaman dilakukan dengan cara membuat lubang tanam sedalam $3-5 \mathrm{~cm}$, setelah itu biji kedelai sebanyak 4 biji dimasukkan langsung pada lubang tanam dan ditimbun dengan tanah. Penyiraman dilakukan rutin setiap hari sesuai kapasitas lapang $(34,93 \%)$ dengan BKM tanah dalam pot $5 \mathrm{~kg}$ sehingga berat tanah dalam pot menjadi $6,75 \mathrm{~kg}$. Panen dilakukan pada saat kedelai berumur 105 hari setelah tanam. Penentuan $\mathrm{N}$ total tanaman dilakukan dengan metode Kjedahl. Sampel ditimbang sebanyak 0,5 g lalu ditambahkan dengan selenium mixture sebanyak $0,5 \mathrm{~g}$ dan $\mathrm{H}_{2} \mathrm{SO}_{4}$ sebanyak $5 \mathrm{ml}$. Kemudian didestruksi selama 30 menit dan didinginkan semalam. Setelah destruksi sampel ditambah $50 \mathrm{ml}$ aquadest, sampel dipindahkan ke labu destilasi dengan ditambahkan $\mathrm{NaOH} 40 \% 10 \mathrm{ml}$ untuk didestilasi selama 15 menit. $\mathrm{NH}_{3}$ yang dibebaskan ditampung dalam erlenmeyer berisi $\mathrm{HCl} 0,1 \mathrm{~N} 10 \mathrm{ml}$ 
yang telah diberi pewarna Conway (merah). Destilat kemudian dititrasi dengan $\mathrm{NaOH} 0,1 \mathrm{~N}$ hingga muncul warna jernih. Hasil kadar nitrogen (\%) ditetapkan menyesuaikan dengan metode Kjedhal [24] untuk masing-masing perlakuan pada jerami dan gabah. Perhitungan serapan nitrogen merupakan hasil kali berat kering sampel dengan kadar nitrogen yang dinyatakan dalam satuan (gN/pot). Analisis data dilakukan dengan menggunakan metode sidik ragam dan apabila berpengaruh nyata dilanjutkan dengan uji beda nilai tengah Duncan Multiple Range Test (DMRT) pada taraf 5\%. Software yang digunakan untuk uji statistik adalah SAS 9.1,3.

\section{HASIL DAN PEMBAHASAN}

\section{Persiapan mikrob Rhizobium dan Fungi Pelarut Fosfat}

Tabel 1 menunjukkan indeks kompatibilitas (IK) antara mikrob R35, R78, dan FPF4. Hasil pengujian kompatibilitas pada dua media tumbuh menunjukkan bahwa isolat R35 memiliki kemampuan untuk tumbuh bersama-sama dengan isolat fungi FPF 4. Hal ini ditunjukkan dengan nilai indeks kompatibilitas dari dua media tumbuh yang digunakan lebih kecil dari 1. Pertumbuhan R35 dan FPF4 yang ditumbuhkan pada media YEMA maupun PDA tidak saling menghambat satu sama lainnya (Gambar 1), diameter pertumbuhan isolat R35 dan FPF4 tidak mengalami penurunan. Reaksi yang sebaliknya terjadi pada isolat R78 dengan isolat FPF4. Pertumbuhan Rhizobium isolat R78 apabila ditumbuhkan bersama-sama dengan FPF4 pada media YEMA ada kecenderungan terhambat (gambar 1). Diameter pertumbuhan isolat R78 lebih kecil apabila ditumbuhkan bersama-sama dengan fungi FPF4. Pertumbuhan FPF4 tidak terganggu dengan kehadiran R78 yang ditunjukkan dengan diameter pertumbuhan yang tetap. Dari pengujian ini dapat diketahui bahwa fungi pelarut fosfat FPF4 yang menghambat pertumbuhan bakteri Rhizobium R78, sedangkan R78 tidak menghambat FPF4.

Tabel 1. Pengujian kompatibilitas mikrob isolat R35, R78, dan FPF4 pada media YEMA dan PDA

\begin{tabular}{lcccccc}
\hline & \multicolumn{3}{c}{ Media YEMA } & & \multicolumn{3}{c}{ Media PDA } \\
\hline Perlakuan & Diameter koloni (cm) & IK & Kompatibilitas & Diameter koloni (cm) & IK & Kompatibilitas \\
\hline R35 & 1,2 & - & - & 3 & - & - \\
R35 x FPF4 & 1,6 & 0,75 & kompatibel & 3,2 & 0,94 & kompatibel \\
R78 & 1,6 & - & - & 1,5 & - & - \\
R78 x FPF4 & 1,5 & 1,06 & tidak kompatibel & 2,5 & 0,6 & kompatibel \\
FPF4 & 3,5 & - & - & 3,4 & - & - \\
FPF4 x R35 & 3,5 & 1 & kompatibel & 4,4 & 0,77 & kompatibel \\
FPF4 x R78 & 3,5 & 1 & kompatibel & 5,6 & 0,61 & kompatibel \\
\hline
\end{tabular}

Keterangan : - = tidak diuji, IK = indeks kompatibilitas

Munculnya reaksi yang tidak kompatibel antara mikrob satu dengan lainnya disebabkan karena rendahnya daya adaptasi mikrob-mikrob yang diuji terhadap lingkungan tumbuhnya. Mikrob yang mampu beradaptasi dapat tumbuh dengan baik dalam lingkungan media tumbuh tanpa mengalami hambatan. Pertumbuhan yang cepat suatu mikrob dapat membatasi ketersediaan sumber karbon, nutrisi, dan ruang bagi pertumbuhan mikrob lainnya dalam suatu lingkungan tumbuh. Selain itu reaksi antagonisme dapat disebabkan juga karena adanya produksi senyawa-senyawa metabolit yang dapat membatasi pertumbuhan mikrob lainnya. Isolat Rhizobium R35 dan isolat fungi pelarut fosfat FPF4 bereaksi kompatibel satu dengan lainnya, yang artinya Rhizobium R35 dan fungi pelarut fosfat FPF4 mampu saling beradaptasi. Penelitian ini menunjukkan bahwa isolat Rhizobium R35 dan fungi pelarut fosfat FPF4 dapat ditumbuhkan secara bersama-sama sebagai suatu kultur campuran dalam media bahan pembawa untuk pengujian selanjutnya. 

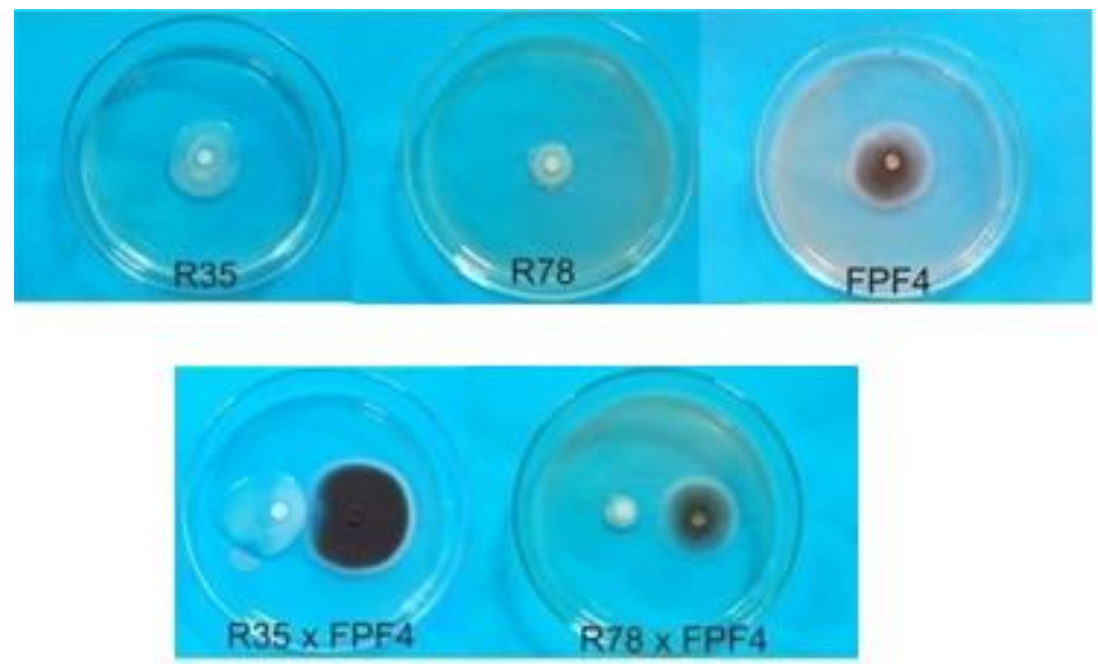

Gambar 1. Pertumbuhan mikrob Rhizobium isolat R35, Rhizobium isolat R78, MPF isolat FPF4, dan kompatibilitasnya.

\section{Pengaruh Komposisi Jenis Bahan Pembawa dan Metode Sterilisasi terhadap pH, $\mathrm{NO}_{3}$, dan $\mathrm{P}$ tersedia}

Perlakuan bahan pembawa berpengaruh terhadap $\mathrm{pH}$ bahan pembawa. Berdasarkan data yang disajikan pada Tabel 6 menunjukkan bahwa baik pemberian biochar maupun fosfat alam mampu meningkatkan $\mathrm{pH}$ bahan pembawa. Nilai $\mathrm{pH}$ pada bahan pembawa paling tinggi diperoleh pada perlakuan biochar $100 \%$, dengan nilai pH lebih tinggi dari gambut Rawa Pening sebesar 20,36\%. Pembakaran biomassa organik dapat menghasilkan abu yang mengandung $\mathrm{Ca}, \mathrm{Mg}$, dan anorganik karbonat. Unsur-unsur inilah yang diduga dapat menjadikan $\mathrm{pH}$ pada biochar yang biasanya diatas netral (alkalis). Sterilisasi bahan pembawa dengan metode iradiasi memiliki nilai $\mathrm{pH}$ yang lebih tinggi bila dibandingkan dengan sterilisasi menggunakan autoclave, seperti yang telah dikemukakan Berns et al. [28] dalam penelitiannya bahwa sterilisasi panas basah memungkinkan pelepasan lebih banyak asam-asam organik pada bahan.

Tabel 2. Pengaruh komposisi bahan pembawa dan metode sterilisasi terhadap terhadap $\mathrm{pH}, \mathrm{NO}_{3}$, dan $\mathrm{P}$ tersedia

\begin{tabular}{|c|c|c|c|c|c|c|}
\hline \multirow{2}{*}{ Bahan pembawa } & \multicolumn{2}{|c|}{$\mathrm{pH}$} & \multicolumn{2}{|c|}{$\mathrm{NO}_{3}(\mathrm{ppm})$} & \multicolumn{2}{|c|}{$\mathrm{P}\left(\mathrm{ppm} \mathrm{P}_{2} \mathrm{O}_{5}\right)$} \\
\hline & autoclave & iradiasi & autoclave & iradiasi & autoclave & iradiasi \\
\hline $\mathrm{b}_{0}=100 \%$ Gambut & $5,45 \mathrm{~d}$ & $5,49 \mathrm{c}$ & $0,44 \mathrm{~b}$ & $0,56 \mathrm{a}$ & $4,01 \mathrm{c}$ & $4,49 \mathrm{~b}$ \\
\hline$b_{1}=50 \%$ Gambut $+50 \%$ Biochar & $5,54 \mathrm{c}$ & $5,55 \mathrm{c}$ & $0,53 \mathrm{a}$ & $0,39 \mathrm{~b}$ & $1,91 \mathrm{c}$ & $6,52 \mathrm{~b}$ \\
\hline $\mathrm{b}_{2}=50 \%$ Gambut $+50 \% \mathrm{FA}$ & $6,60 \mathrm{a}$ & $6,76 \mathrm{a}$ & $0,25 d$ & $0,25 c$ & $5,01 \mathrm{c}$ & $6,32 b$ \\
\hline $\begin{array}{l}b_{3}=50 \% \text { Gambut }+25 \% \text { Biochar }+ \\
25 \% \text { FA }\end{array}$ & $6,49 b$ & $6,51 \mathrm{~b}$ & $0,20 \mathrm{~d}$ & $0,25 \mathrm{c}$ & $15,24 b$ & $3,74 b$ \\
\hline $\mathrm{b}_{4}=100 \%$ Biochar & $6,56 \mathrm{ab}$ & $6,75 a$ & $0,36 \mathrm{c}$ & $0,17 \mathrm{c}$ & 99,16 a & $110,01 \mathrm{a}$ \\
\hline
\end{tabular}

Angka yang diikuti huruf yang sama pada kolom yang sama tidak berbeda nyata berdasarkan uji DMRT $5 \%$.

Pengaruh metode sterilisasi terhadap kandungan nitrat tersedia dalam bahan pembawa juga diamati. Hal ini penting dilakukan karena nitrat dapat mempengaruhi efektivitas Rhizobium dalam mengikat $\mathrm{N}_{2}$. Penelitian Bisseling et al. [29] menunjukkan bahwa penambahan $\mathrm{NH}_{4} \mathrm{NO}_{3}$ dapat menurunkan jumlah leghemoglobin pada nodul, dan ada korelasi antara kandungan leghemoglobin dengan kapasitas mengikat nitrogen dari nodul. Penurunan kandungan leghemoglobin pada nodul akar akan menurunkan kemampuan pengikatan nitrogen oleh Rhizobium. Proses pembentukan nitrat di dalam tanah pada umumnya hasil dari oksidasi amonium. Pertama ion amonium akan dioksidasi oleh Nitrosomonas $\left(\mathrm{NO}_{2}^{-}\right)$menjadi nitrit, kemudian nitrit akan dioksidasi oleh oleh Nitrobacter menjadi nitrat $\left(\mathrm{NO}_{3}{ }^{-}\right)$. Pada penelitian ini bahan pembawwa yang digunakan telah mengalami perlakuan sterilisasi sehingga proses pembentukan nitrat secara biologis tidak terjadi, diduga nitrat yang 
terkandung pada bahan pembawa merupakan akumulasi dari sisa proses yang terjadi sebelumnya dan terjerap pada permukaan masing-masing jenis bahan pembawa. Senyawa $\mathrm{N}$ (nitrogen) di alam terdapat dalam berbagai bentuk, yaitu $\mathrm{N}$ organik, $\mathrm{N}$ ammonia, $\mathrm{N}-\mathrm{NO}_{3}, \mathrm{~N}-\mathrm{NO}_{2}$, dan gas $\mathrm{N}_{2}$. Diduga metode sterilisasi mempengaruhi dalam melepaskan ikatan-ikatan nitrat dengan senyawa lain di dalam bahan, sehingga ini menjelaskan mengapa nitrat dalam penelitian ini nilainya berfluktuatif.

Kelarutan nitrat cenderung rendah pada bahan biochar dan bahan yang diberi campuran biochar, baik yang disterilisasi dengan autoclave maupun dengan iradiasi sinar gamma Co-60. Perlakuan biochar $100 \%\left(b_{4}\right)$ dengan metode autoclave (a) mampu menahan kelarutan nitrat 1,2 kali bila dibandingkan bahan gambut Rawa Pening. Sedangkan bila dengan metode iradiasi $(r)$ bahan pembawa biochar $100 \%\left(b_{4}\right)$ mampu menahan 3,29 kali dari bahan pembawa gambut Rawa Pening. Hasil ini sesuai dengan apa yang dilaporkan Cheng et al. [30] bahwa penambahan biochar mampu mempertahankan $\mathrm{NO}_{3}{ }^{-}$dalam tanah, sehingga $\mathrm{NO}_{3}{ }^{-}$yang terlarut semakin kecil. Penurunan kelarutan nitrat pada tanah dengan penambahan biochar dilaporkan juga oleh Yao et al. [31], dari hasil penelitiannya biochar PH600 dapat mengurangi pencucian nitrat dan amonium masing-masing sebanyak $34 \%$ dan $14 \%$, namun dilain sisi dapat menyebabkan pelepasan fosfat tambahan dari tanah. P tersedia pada bahan pembawa $b_{4}$ (biochar) menunjukkan nilai yang lebih tinggi bila dibandingkan dengan jenis komposisi bahan pembawa lainnya. Nilai $\mathrm{P}$ tersedia pada biochar yang disterilisasi dengan autoclave dan iradiasi sinar gama masing-masing adalah 24,73 kali dan 24,50 kali dari nilai $P$ tersedia gambut Rawa Pening. Tingginya $P$ tersedia dalam bahan biochar salah satunya diduga karena sumbangan kandungan $\mathrm{P}$ yang berasal dari bahan dasar sekam padi. Selain itu, nilai fosfat tersedia dalam bahan pembawa yang terdeteksi salah satunya dikarenakan sumbangan dari P organik yang berasal dari mikrob yang mati akibat sterilisasi. Menurut Subba-Rao [32] fosfor organik mengandung senyawa yang berasal dari tanaman dan mikroorganisme dan tersusun dari asam nukleat, fosfolipid, dan fitin. Fosfat tersedia dalam gambut asal Rawa Pening dapat terikat pada humus melalui perantaraan kation-kation. Dengan nilai KTK yang tinggi pada gambut Rawa Pening maka pelepasan $P$ pada larutan tanah dapat meningkat karena adanya pemutusan ikatan-ikatan kimia oleh metode sterilisasi baik karena pemanasan maupun iradiasi. Peningkatan $\mathrm{pH}$ yang terjadi pada bahan pembawa juga mempengaruhi ketersediaan $\mathrm{P}$, sehingga dengan meningkatnya $\mathrm{pH}$ maka kelarutan $\mathrm{P}$ juga meningkat.

\section{Uji Viabilitas Rhizobium R35 dan Fungi Pelarut Fosfat FPF4 dalam Jenis Bahan Pembawa Berbeda}

Isolat-isolat yang diinokulasikan pada lima komposisi bahan pembawa pupuk hayati setelah disimpan pada suhu kamar masih mampu bertahan hidup sampai dengan pengamatan bulan ke 3 (Tabel 3). Hal ini salah satunya dikarenakan mikrob Rhizobium dan fungi pelarut fosfat saling kompatibel dalam bahan pembawa. Pengamatan bulan 1 setelah inokulasi, mikrob Rhizobium isolat R35 mengalami reaksi yang ditunjukkan dengan pertumbuhan koloni yang berbeda pada setiap jenis komposisi bahan pembawa. Pada pengamatan bulan 1 , bahan pembawa jenis gambut rawa pening $\left(b_{0}\right)$ dengan metode sterilisasi autoclave $(a)$ menunjukkan nilai jumlah mikrob Rhizobium paling tinggi bila dibandingkan jumlah mikrob Rhizobium R35 yang terdapat pada komposisi bahan yang lainnya. Pada pengamatan bulan ke-2 dan bulan ke-3, mikrob Rhizobium isolat R35 pada bahan pembawa gambut rawa pening ( $\left.b_{0}\right)$ dengan metode autoclave (a) mulai mengalami penurunan populasi sel masing-masing sebesar $44,89 \%$ dan $66,85 \%$ dari jumlah sel bulan ke 1 . Tingginya jumlah Rhizobium isolat R35 pada pengamatan bulan ke 1 diduga karena kultur mikrob yang ditambahkan pada komposisi jenis bahan pembawa pada fase eksponensial. Pada fase ini mikrob sedang aktif tumbuh, selain itu bahan yang ditambahkan masih berupa media kultur cair YEM, sehingga nutrisi dan sumber energi masih cukup tinggi untuk dapat bereproduksi. Pengamatan bulan ke 2 mulai terjadi penurunan pada jumlah sel Rhizobium isolat R35 dalam komposisi bahan gambut $\left(b_{0}\right)$ baik dengan metode sterilisasi autoclave maupun iradiasi gamma Co-60. Hal ini diduga karena mulai terbatasnya nutrisi untuk tumbuh dan efek yang ditimbulkan dari lingkungan bahan pembawa seperti perubahan kandungan oksigen, karbon, dan zat-zat metabolit lain yang mungkin timbul. Rhizobium isolat R35 diduga tidak mampu tumbuh secara optimal ketika terdapat peningkatan unsur-unsur seperti $\mathrm{Mn}^{2+}, \mathrm{Fe}^{2+}$, dan $\mathrm{Zn}^{2+}$ karena pengaruh metode sterilisasi [33] pada gambut Rawa Pening. Perubahan $\mathrm{pH}$, nitrat, dan kelarutan $P$ nampaknya juga mempengaruhi populasi mikrob dalam bahan pembawa.

Pengamatan pada bulan ke-2 dan bulan ke-3 jumlah sel isolat Rhizobium isolat R35 paling tinggi diperoleh masing-masing pada komposisi jenis bahan pembawa $b_{2} r$ (gambut+fosfat alam dengan metode 
sterilisasi iradiasi) dan b4r (biochar dengan metode iradiasi). Hal ini menunjukkan bahwa komposisi jenis bahan pembawa dan perubahan karakter bahan pembawa berpengaruh terhadap pertumbuhan Rhizobium isolat R35. Keadaan lingkungan dalam bahan pembawa dapat memberikan pengaruh terhadap pertumbuhan isolat Rhizobium R35. Seperti pada umumnya bahwa Rhizobium memerlukan kondisi lingkungan tumbuh yang optimal dengan tingkat kemasaman yang relatif netral. Perubahan karakter kimia pada bahan pembawa seperti pada $\mathrm{pH}$, $\mathrm{P}$ tersedia, dan $\mathrm{NO}_{3}$ terlarut diduga turut mempengaruhi viabilitas sel dalam bahan pembawa selama masa penyimpanan. Hasil pengamatan viabilitas selama 3 bulan penyimpanan menunjukkan lama penyimpanan inokulum spora fungi pelarut fosfat FPF4 dalam berbagai komposisi bahan berpengaruh pada viabilitas mikrob pelarut fosfat FPF4. Pada pengamatan bulan ke 1 jumlah mikrob FPF4 yang tertinggi diperoleh pada komposisi bahan pembawa $100 \%$ gambut dengan metode sterilisasi iradiasi gamma Co-60 (a). Tingginya jumlah viabilitas pada bulan ke 1 pada bahan pembawa gambut diduga karena fungi yang merupakan organisme heterotrof yang memerlukan senyawa organik sebagai sumber energinya. Dalam hal ini, diduga fungi pelarut fosfat FPF4 selain memperoleh energi dari media PDB, juga dapat memanfaatkan dan menggunakan sumber energi dari bahan organik yang berasal dari gambut. Pada bulan ke 2 jumlah koloni FPF4 pada komposisi bahan pembawa gambut rawa pening dengan metode pemanasan autoclave $\left(\mathrm{b}_{0} \mathrm{a}\right)$ mengalami peningkatan sebesar $66.67 \%$ dari pengamatan bulan 1. Pengamatan pada bulan 3 jumlah pertumbuhan koloni fungi pelarut fosfat mulai mengalami penurunan sebesar $70.83 \%$ dari pengamatan bulan ke 1 .

Tabel 3. Pengaruh jenis bahan pembawa dan metode sterilisasi terhadap viabilitas mikrob Rhizobium R35 dan fungi pelarut fosfat FPF4.

\begin{tabular}{|c|c|c|c|c|c|c|c|}
\hline \multirow{3}{*}{ Bahan pembawa } & \multirow{3}{*}{ Sterilisasi } & \multicolumn{6}{|c|}{ Waktu Penyimpanan (bulan) } \\
\hline & & \multicolumn{3}{|c|}{$\begin{array}{c}\text { Rhizobium (R35) } \\
\left(\mathrm{x} 10^{8} \mathrm{cfu} / \mathrm{g}\right)\end{array}$} & \multicolumn{3}{|c|}{$\begin{array}{c}\text { Fungi Pelarut Fosfat (FPF4) } \\
\left(\mathrm{x} 10^{6} \mathrm{cfu} / \mathrm{g}\right)\end{array}$} \\
\hline & & 1 bulan & 2 bulan & 3 bulan & 1 bulan & 2 bulan & 3 bulan \\
\hline$b_{0}=100 \%$ Gambut & $\begin{array}{l}\text { autoclave (a) } \\
\text { iradiasi (r) }\end{array}$ & $\begin{array}{l}3,23 \\
0,97\end{array}$ & $\begin{array}{l}1,78 \\
0,23\end{array}$ & $\begin{array}{l}1,20 \\
5,43\end{array}$ & $\begin{array}{l}1,20 \\
6,13\end{array}$ & $\begin{array}{l}2,00 \\
1,50\end{array}$ & $\begin{array}{l}0,35 \\
1,70\end{array}$ \\
\hline \multirow[t]{2}{*}{$b_{1}=50 \%$ Gambut $+50 \%$ Biochar } & autoclave (a) & 1,42 & 4,04 & 5,37 & 5,37 & 2,60 & 0,28 \\
\hline & iradiasi (r) & 1,34 & 4,13 & 3,20 & 3,20 & 1,70 & 1,13 \\
\hline \multirow[t]{2}{*}{$\mathrm{b}_{2}=50 \%$ Gambut $+50 \% \mathrm{FA}$} & autoclave (a) & 1,19 & 3,87 & 3,63 & 0,51 & 0,25 & 0,51 \\
\hline & iradiasi (r) & 1,26 & 7,03 & 4,93 & 4,30 & 1,17 & 0,57 \\
\hline \multirow{2}{*}{$\begin{array}{l}\mathrm{b}_{3}=50 \% \text { Gambut }+25 \% \\
\text { Biochar }+25 \% \mathrm{FA}\end{array}$} & autoclave (a) & 1,12 & 1,79 & 3,27 & 0,40 & 0,36 & 0,40 \\
\hline & iradiasi $(r)$ & 1,15 & 2,61 & 1,83 & 2,50 & 1,83 & 2,50 \\
\hline \multirow[t]{2}{*}{$\mathrm{b}_{4}=100 \%$ Biochar } & autoclave (a) & 1,20 & 0,76 & 5,43 & 0,49 & 1,97 & 0,85 \\
\hline & iradiasi (r) & 1,88 & 0,18 & 5,90 & 3,60 & 7,53 & 3,60 \\
\hline
\end{tabular}

Hasil pengamatan bulan ke 2 jumlah koloni fungi pelarut fosfat FPF 4 paling tinggi didapatkan pada komposisi bahan biochar $\left(b_{4}\right)$ dengan metode sterilisasi iradiasi gamma Co-60 (r) (Tabel 3). Pada bulan ke 2 jumlah koloni fungi FPF4 pada $b_{4} r$ mengalami peningkatan sebesar $109,17 \%$ dari pengamatan bulan 1 , namun pada pengamatan bulan ke 3 jumlah koloni fungi pelarut fosfat FPF4 pada b4r kembali menurun dan menunjukkan jumlah koloni yang sama pada saat pengamatan bulan ke 1. Jumlah populasi tertinggi pada bulan ke 3 diperoleh pada komposisi bahan pembawa biochar $\left(b_{4}\right)$ dengan sterilisasi iradiasi gamma Co-60 ( $r$ ). Viabilitas mikrob pelarut fosfat isolat FPF4 cenderung fluktuatif, hal ini dapat terjadi karena diduga terjadi perubahan jumlah nutrisi di dalam bahan serta adanya pengaruh perubahan kondisi lingkungan pada mikrob yang ditambahkan. Fungi pelarut fosfat FPF4 yang dimasukan ke dalam jenis komposisi bahan pembawa berbentuk spora. Spora merupakan salah satu bentuk produk fungi untuk melakukan perbanyakan dengan cara aseksual. Spora yang dihasilkan fungi memiliki kemampuan yang berbeda untuk dapat bertahan, matang, berkecambah, dan membentuk tubuh buah. Spora-spora yang tidak tahan terhadap perubahan lingkungan dan belum matang tidak akan berkecambah, sehingga tidak akan tumbuh menjadi tubuh buah dan koloni fungi yang 
baru. Hal ini mengakibatkan terjadinya perbedaan jumlah koloni yang muncul pada setiap komposisi media selama penyimpanan. Hasil pengujian ini menunjukkan bahwa bahan pembawa biochar $\left(b_{4}\right)$ dengan metode iradiasi ( $r$ ) lebih baik dalam mempertahankan jumlah mikrob. Hale et al. [34] menyatakan bahwa sifat kimia biochar, terutama nitrogen dan $\mathrm{pH}$, merupakan karakteristik yang paling penting yang mempengaruhi kelangsungan hidup inokulum awal dan mungkin berpengaruh pada umur simpan.

\section{Pengaruh Bahan Pembawa Pupuk Hayati terhadap Hasil Kedelai Varietas Mutiara 3}

Hasil sidik ragam yang disajikan pada Tabel 4 menunjukkan serapan $\mathrm{N}$ pada brangkasan nilainya tidak berbeda nyata dengan kontrol namun nilai serapan $\mathrm{N}$ pada perlakuan pupuk hayati yang disertai penambahan $50 \%$ pupuk NP rekomendasi masih lebih tinggi daripada kontrol. Rendahnya serapan N pada brangkasan kedelai karena $\mathrm{N}$ yang diserap oleh tanaman yang sudah berumur panen telah didistribusikan ke dalam biji tanaman kedelai. Perlakuan $\mathrm{b}_{4} \mathrm{r}+50$ memberikan pengaruh tertinggi pada serapan $\mathrm{N}$ pada biji tanaman kedelai dengan nilai peningkatan sebesar $41.91 \%$ dari kontrol. Nilai tersebut tidak berbeda nyata dengan pemberian pupuk $\mathrm{N}$ dan $\mathrm{P}$ $100 \%$ yang memberikan peningkatan serapan $N$ dari kontrol sebanyak $31,88 \%$. Peningkatan serapan $N$ ini diduga karena mikrob Rhizobium isolat R35 dan mikrob pelarut fosfat FPF4 mampu bertahan dalam bahan pembawa $b_{4} r$ yang ditambahkan, sehingga masing-masing mikrob dalam jumlah yang tinggi (lihat Tabel 3 ) dan dapat membantu penyerapan N. Peningkatan serapan $\mathrm{N}$ pada biji kedelai pada perlakuan $\mathrm{b}_{4} \mathrm{r}+50$, selain karena sumbangan dari fiksasi $\mathrm{N}$ oleh Rhizobium R35 juga karena adanya pengaruh dari bahan pembawa biochar. Diduga biochar dapat mempertahankan sejumlah $\mathrm{N}$ terutama dalam bentuk $\mathrm{NO}_{3}{ }^{-}$dalam rhizosfer (lihat Tabel 2) sehingga nitrat terlarut yang terjerap dalam permukaan biochar dan dapat dimanfaatkan oleh tanaman. Menurut Prendergast-Miller et al. [35] bahwa tanah-tanah yang diberi biochar mampu mempertahankan nitrat dari pencucian di daerah perakaran tanaman sehingga meningkatkan efisiensi penyerapan $\mathrm{N}$ oleh tanaman. Pengaruh bahan pembawa biochar $\left(b_{4}\right)$ dengan metode autoclave (a) maupun dengan metode iradiasi $(r)$ memberikan nilai serapan $\mathrm{N}$ yang tidak berbeda nyata, namun nilai serapan $\mathrm{N}$ dengan iradiasi sinar gamma cenderung lebih tinggi (Tabel 4). Pemberian pupuk urea dan SP-36 sebanyak $50 \%$ (NPK) menyebabkan terjadinya pelepasan $\mathrm{N}$ dan $\mathrm{P}$ lebih banyak ke dalam tanah, dan menjadi nutrisi tersedia yang langsung dapat diserap tanaman. Hal ini menyebabkan nilai serapan $\mathrm{N}$ dan serapan $\mathrm{P}$ pada brangkasan kedelai yang diberi formula pupuk hayati disertai pupuk 50\% (NPK) nilainya lebih tinggi bila dibandingkan pemberian formula pupuk hayati saja.

Peningkatan serapan $P$ tertinggi pada brangkasan kedelai diperoleh pada perlakuan $b_{4} r+50$ dan nilainya tidak berbeda nyata dengan pemberian pupuk kimia 100\% (NPK). Peningkatan yang terjadi pada pemberian perlakuan $b_{4} r+50$ terhadap serapan $P$ brangkasan kedelai sebanyak $96,22 \%$ dari kontrol. Nilai serapan $P$ tertinggi pada biji kedelai juga diperoleh pada perlakuan $b_{4} r+50$ dengan nilai peningkatan sebesar $9.68 \%$ dari kontrol. Hasil ini menunjukkan bahwa pemberian pupuk hayati dengan bahan pembawa biochar $\left(b_{4}\right)$ metode iradiasi $(r)$ mampu mengurangi penggunaan pupuk kimia NPK sebesar $50 \%$ dari dosis rekomendasi. Komposisi bahan pembawa pupuk hayati berpengaruh terhadap peningkatan berat kering biji kedelai. Pemberian bahan pembawa pupuk hayati tidak berpengaruh terhadap jumlah bintil akar, jumlah polong tanaman, dan berat kering tanaman kedelai varietas Mutiara 3. Namun terjadi peningkatan terhadap hasil berat kering biji kedelai. Nilai berat kering biji kedelai tertinggi diperoleh oleh perlakuan bahan pembawa $b_{4} r+50 \%$ dengan peningkatan sebesar $41,23 \%$ dari kontrol. Peningkatan ini diduga karena peranan biochar dalam mempertahankan jumlah mikrob dalam tanah, dan membuat daerah perakaran menjadi habitat yang baik bagi pertumbuhan mikrob sehingga dapat mendukung mikrob dan pertumbuhan tanaman. Penelitian Hale et al. [36] menyimpulkan bahwa ketika sel Enterobacter cloacae UW5 diinokulasikan ke dalam biochar kerapatannya meningkat seiring bertambahnya waktu. Hal yang sama terjadi apabila biochar yang mengandung sel Enterobacter cloacae UW5 diaplikasikan ke dalam tanah. 
Tabel 4. Pengaruh formula pupuk hayati terhadap jumlah bintil akar, serapan $\mathrm{N}$ (mg N/pot) dan $\mathrm{P}$ (mg P/pot) pada biji kedelai varietas Mutiara 3 dan berat kering biji kedelai (g/pot)

\begin{tabular}{|c|c|c|c|c|}
\hline Perlakuan & $\begin{array}{c}\text { Jumlah bintil } \\
\text { akar (buah/pot) }\end{array}$ & $\begin{array}{c}\text { Serapan P biji } \\
\text { kedelai (mg P/pot) }\end{array}$ & $\begin{array}{c}\text { Serapan N biji } \\
\text { kedelai (mg N/pot) }\end{array}$ & $\begin{array}{l}\text { Berat kering biji } \\
\text { kedelai (g/pot) }\end{array}$ \\
\hline boa+Rhizobium R35+ FPF4 & $24 \mathrm{a}$ & $34,09 \mathrm{~d}$ & $364,94 \mathrm{c}$ & $5,88 \mathrm{c}$ \\
\hline bortRhizobium R35+ FPF4 & $20 \mathrm{a}$ & $36,40 \mathrm{~cd}$ & $349,60 \mathrm{c}$ & $6,04 \mathrm{bc}$ \\
\hline $\mathrm{b}_{1} \mathrm{a}+$ Rhizobium R35+FPF4 & $24,75 \mathrm{a}$ & $49,84 \mathrm{abcd}$ & $463,55 a b c$ & $7,55 a b c$ \\
\hline $\mathrm{b}_{1} \mathrm{r}+$ Rhizobium R35+FPF4 & $26,5 \mathrm{a}$ & $51,58 \mathrm{abcd}$ & $525,77 \mathrm{a}$ & $8,45 \mathrm{a}$ \\
\hline $\mathrm{b}_{2} \mathrm{a}+$ Rhizobium R35+FPF4 & $23,75 a$ & $35,70 \mathrm{~d}$ & $371,32 \mathrm{bc}$ & $6,17 \mathrm{bc}$ \\
\hline $\mathrm{b}_{2} \mathrm{r}+$ Rhizobium R35+ FPF4 & 25,5 a & $41,36 \mathrm{bcd}$ & $428,49 a b c$ & $7,15 a b c$ \\
\hline $\mathrm{b}_{3} \mathrm{a}+$ Rhizobium R35+FPF4 & $25,5 \mathrm{a}$ & $41,19 \mathrm{bcd}$ & $456,68 \mathrm{abc}$ & $7,77 \mathrm{abc}$ \\
\hline $\mathrm{b}_{3} \mathrm{r}+$ Rhizobium R35+FPF4 & 28,5 a & $45,70 \mathrm{abcd}$ & $483,84 a b$ & $7,77 a b c$ \\
\hline $\mathrm{b}_{4} \mathrm{a}+$ Rhizobium R35+FPF4 & $28 \mathrm{a}$ & $42,25 \mathrm{bcd}$ & $426,03 a b c$ & $6,87 \mathrm{abc}$ \\
\hline $\mathrm{b}_{4}+$ +Rhizobium R35+FPF4 & $26 \mathrm{a}$ & 45,44 abcd & $454,90 \mathrm{abc}$ & $7,63 a b c$ \\
\hline $\mathrm{b}_{0} \mathrm{a}+$ Rhizobium R35+FPF4 + 50\% NPK & 32,5 a & $42,26 \mathrm{bcd}$ & $483,53 \mathrm{ab}$ & $7,90 \mathrm{abc}$ \\
\hline bort+Rhizobium R35+FPF4 + 50\% NPK & 19,5 a & $50,41 \mathrm{abcd}$ & 501,36 a & $8,11 a b$ \\
\hline $\mathrm{b}_{1} \mathrm{a}+$ Rhizobium R35 + FPF $4+50 \%$ NPK & $25,75 \mathrm{a}$ & $46,59 \mathrm{abcd}$ & 505,94 a & $8,16 \mathrm{ab}$ \\
\hline $\mathrm{b}_{1} \mathrm{r}+$ Rhizobium R35 + FPF $4+50 \%$ NPK & $27,25 \mathrm{a}$ & $55,75 a b$ & $499,91 \mathrm{a}$ & $8,05 \mathrm{ab}$ \\
\hline $\mathrm{b}_{2} \mathrm{a}+$ Rhizobium R35 + FPF $4+50 \%$ NPK & $27,75 a$ & $54,69 \mathrm{abc}$ & $528,59 \mathrm{a}$ & $8,38 \mathrm{a}$ \\
\hline $\mathrm{b}_{2} \mathrm{r}+$ Rhizobium R35 + FPF $4+50 \%$ NPK & 24,5 a & $55,29 \mathrm{ab}$ & $495,21 \mathrm{a}$ & $8,01 a b c$ \\
\hline $\mathrm{b}_{3} \mathrm{a}+$ Rhizobium R35 + FPF $4+50 \%$ NPK & $19,75 a$ & $54,95 \mathrm{ab}$ & 511,24 a & $8,53 a$ \\
\hline $\mathrm{b}_{3} \mathrm{r}+$ Rhizobium R35 + FPF $4+50 \%$ NPK & $32,75 a$ & $54,64 a b$ & $500,85 a$ & $8,13 \mathrm{ab}$ \\
\hline $\mathrm{b}_{4 \mathrm{a}}+$ Rhizobium R35 + FPF $4+50 \%$ NPK & 24,5 a & $56,51 \mathrm{ab}$ & $436,80 a b c$ & $7,65 a b c$ \\
\hline $\mathrm{b}_{4} \mathrm{r}+$ Rhizobium R35 + FPF $4+50 \%$ NPK & $35,25 \mathrm{a}$ & $61,04 a$ & $520,45 \mathrm{a}$ & $8,53 \mathrm{a}$ \\
\hline $50 \%$ pupuk NPK & $25,25 \mathrm{a}$ & $57,37 \mathrm{ab}$ & $373,28 \mathrm{bc}$ & $6,99 a b c$ \\
\hline $100 \%$ pupuk NPK & 26,5 a & $54,26 \mathrm{abc}$ & $483,67 \mathrm{ab}$ & $8,51 \mathrm{a}$ \\
\hline kontrol & $12,25 \mathrm{a}$ & $55,65 a b$ & $366,74 \mathrm{c}$ & $6,04 \mathrm{bc}$ \\
\hline
\end{tabular}

Angka yang diikuti huruf yang sama pada kolom yang sama tidak berbeda nyata berdasarkan uji DMRT $5 \%$.

Biochar dapat melindungi mikrob dari cekaman lingkungan sehingga dapat meningkatkan daya tahan selama dalam tanah dan proses kolonisasi akar. Dalam pengamatan jumlah mikrob akhir pada bulan ke 3 menunjukkan bahwa mikrob pelarut fosfat FPF4 dalam bahan pembawa biochar dengan metode iradiasi $\left(b_{4} r\right)$ masih dalam jumlah tinggi. Tingginya jumlah mikrob dapat mempengaruhi kelarutan fosfat dalam tanah sehingga fosfat yang larut dapat langsung diserap tanaman kedelai. Hasil ini menunjukkan bahwa ( $b_{4} r$ ) berpotensi dijadikan sebagai bahan pembawa pupuk hayati untuk peningkatan produksi kedelai varietas Mutiara 3. Metode sterilisasi baik dengan iradiasi maupun dengan autoclave tidak berpengaruh nyata terhadap pertumbuhan dan hasil tanaman kedelai varietas Mutiara 3 secara langsung. Bahan pembawa yang diberikan pada tanaman dalam jumlah sedikit yaitu hanya sekitar $0,3 \mathrm{~g} / \mathrm{biji}$ sehingga perubahan kimia seperti $\mathrm{pH}$, kelarutan nitrat, dan $\mathrm{P}$ tersedia yang muncul pada komposisi bahan pembawa akibat metode sterilisasi tidak mempengaruhi pertumbuhan tanaman kedelai secara langsung.

\section{KESIMPULAN}

Metode sterilisasi dengan iradiasi pada bahan pembawa menunjukkan nilai $\mathrm{pH}$ yang lebih tinggi bila dibandingkan sterilisasi dengan autoclave. Bahan pembawa biochar $100 \%\left(b_{4}\right)$ dengan metode iradiasi $(r)$ mampu mengurangi kelarutan nitrat lebih tinggi bila dibandingkan dengan autoclave. Kelarutan $\mathrm{P}_{2} \mathrm{O}_{5}$ pada bahan pembawa dengan metode sterilisasi iradiasi lebih tinggi bila dibandingkan dengan metode autoclave. Sterilisasi bahan pembawa dengan iradiasi sinar gamma Co-60 pada $30 \mathrm{kGy}$ lebih baik karena populasi mob dan fungi pelarut fosfat FPF4 menunjukkan nilai populasi yang lebih tinggi bila dibandingkan dengan sterilisasi menggunakan autoclave. Bahan pembawa pupuk hayati yang disterilisasi dengan iradiasi sinar gamma Co-60 lebih baik terhadap peningkatan produksi kedelai Mutiara 3. Nilai berat kering biji kedelai tertinggi diperoleh pada 
perlakuan bahan pembawa biochar yang diiradiasi sinar gamma C-60 dengan peningkatan sebesar $41,23 \%$ dari kontrol.

\section{Ucapan terima kasih}

Terima kasih disampaikan kepada Kementerian Riset Teknologi dan Pendidikan Tinggi yang telah memberikan bantuan dana penelitian melalui program Beasiswa Kemenristekdikti tahun 2014. Ucapan terima kasih juga penulis sampaikan kepada Bapak Sudono Slamet, Budi Leksono, dan Andika dari Laboratorium Pemupukan dan Nutrisi Tanaman PAIR BATAN yang telah membantu dalam analisis sampel tanaman dan tanah.

\section{DAFTAR PUSTAKA}

[1] D. Riniasih. Outlook Komoditas Pertanian Tanaman Pangan Kedelai, Pusat Data dan Sistem Informasi Pertanian Kementerian Pertanian, ISSN : 1907 - 1507, Jakarta, 2016.

[2] T. White. Corn Yield and Soybean Production Up in 2017, USDA Reports Winter Wheat Seedings and Grain Stocks also reported https://www.nass.usda.gov/Newsroom/2018/01_12_2018.php

[3] A. Ispandi dan A. Munip, "Efektifitas Pengapuran Terhadap Serapan Hara dan Produksi Beberapa Klon Ubikayu di Lahan Kering Masam", IImu Pertanian, Vol. 12, No.2, pp. 125 - 139, 2005.

[4] R. Rosliani, Y. Hilman, dan N. Sumarni. "Pemupukan Fosfat Alam, Pupuk Kandang Domba, dan Inokulasi Cendawan Mikoriza Arbuskula terhadap Pertumbuhan dan Hasil Tanaman Mentimun pada Tanah Masam". J. Hortikultura. Vol.16 No.1 pp. 21-30, 2006.

[5] A. Wijanarko, B.H. Purwanto, D. Shiddieq, D. Indradewa, "Pengaruh Kualitas Bahan Organik dan Kesuburan Tanah Terhadap Mineralisasi Nitrogen dan Serapan N Oleh Tanaman Ubikayu di Ultisol". J. Perkebunan \& Lahan Tropika, Vol. 2, No.2, pp. 1-14, 2012.

[6] B.N. Fitriatin, A. Yuniarti, O. Mulyani, F.S. Fauziah, dan M.D. Tiara, "Pengaruh Mikroorganisme Pelarut Fosfat Dan Pupuk P terhadap P Tersedia, Aktivitas Fosfatase, Populasi Mikroorganisme Pelarut Fosfat, Konsentrasi P Tanaman dan Hasil Padi Gogo (Oryza sativa. L.) pada Ultisols", Jurnal Agrikultura, Vol. 20, No. 3, pp. 210-215, 2009.

[7] R.D. Ningsih dan I. Anas, "Tanggap Tanaman Kedelai terhadap Inokulasi Rhizobium dan Asam Indol Asetat (IAA) pada Ultisol Darmaga", Bul. Agron. Vol. 32, No.2, pp. 25 - 32, 2004.

[8] K.G. Cassman, A.S. Whitney, R.L. Fox, "Phosphorus Requirements of Soybean and Cowpea as Affected by Mode of N Nutrition", Agronomy Journal, Vol. 73, pp. 17-22, 1981.

[9] N.K. Arora, E. Khare, and D.K. Maheshwari, "Plant Growth Promoting Rhizobacteria: Constraints in Bioformulation, Commercialization, and Future Strategies", Plant Growth and Health Promoting Bacteria, Vol. 18, pp. 97-116, 2010.

[10] Haryanto, K. Idris, R.I. Kawalusan, dan E.L. Sisworo, "Pengaruh Pupuk Fosfat Alam Pada Tanah Masam Terhadap Pertumbuhan Jagung Serta Serapan N-ZA dan N-Urea", Jurnal IImiah Aplikasi Isotop dan Radiasi, Vol. 4, No.2, pp. 130-142, 2008.

[11] M. Jayadi, Baharuddin, B. Ibrahim, "In vitro selection of rock phosphate solubility by microorganism from Ultisols in South Sulawesi, Indonesia", American Journal of Agriculture and Forestry, Vol. 1, No.4, pp. 6873, 2013.

[12] L. Herrmann and D. Lesueur 2013. "Challenges of formulation and quality of biofertilizers for successful inoculation", Appl Microbiol Biotechnol. Vol. 97, pp. 8859-8873, 2013.

[13] Y. Bashan Y, L.E. de-Bashan, S.R. Prabhu SR, J.P. Hernandez JP, "Advances in plant growth-promoting bacterial inoculant technology: formulations and practical perspectives (1998-2013)", Plant Soil. Vol 378, pp.1-33, 2014.

[14] F. Hazra dan E. Widyati, "Isolasi, Seleksi Bahan Pembawa dan Formulasi Inokulum Thiobacillus spp.", Jurnal Tanah dan Lingkungan, Vol. 9, No.2, pp. 71-76. 2007. 
[15] A. Gandhi dan K. Sivakumar, "Impact of vermicompost carrier based bioinoculants on the growth, yield and quality of rice (Oriza sativa L.) C.V. NLR 145", The Ecoscan Vol. 4, No.1, pp. 83-88. 2010.

[16] M. Albareda, D.N. Rodri'guez-Navarr, M. Camacho, F.J. Temprano. "Alternatives to peat as a carrier for rhizobia inoculants: solid and liquid formulations", Soil Biology \& Biochemistry, Vol. 40, pp. 1-9, 2008.

[17] A. Daza, C. Santamaria, D.N. Rodri'guez-Navarro, M. Camacho, R. Orive, F.J. Temprano. "Perlite as a carrier for bacterial inoculants", Soil Biology \& Biochemistry, Vol. 32, pp. 567-572, 2000.

[18] Saranya, P.S. Krishnan, K. Kumutha and J. French, "Potential for Biochar as an Alternate Carrier to Lignite for the Preparation of Biofertilizers in India", Int. Jr. of Agril., Env. and Biotech. Vol. 4, No.2, pp. 167-172, 2011.

[19] C.N. Kelly, F.C. Calderon, V. Acosta-Martinez, M.M. Mikha, J. Benjamin, D.W. Rutherford and C.E. Rostad CE, "Switchgrass Biochar Effects on Plant Biomass and Microbial Dynamics in Two Soils from Different Regions". Pedosphere, Vol. 25, No.3, pp. 329-342, 2015.

[20] P. Tittabutr, K. Teamthisong, B. Buranabanyat, N. Teaumroong, N. Boonkerd, "Gamma Irradiation and Autoclave Sterilization Peat and Compost as the Carrier for Rhizobial Inoculant Production", Journal of Agricultural Science. Vol.12, pp. 59-67. 2012.

[21] Hanudin, B. Marwoto, Hersanti, A. Muharam, "Kompatibilitas Bacillus subtilis, Pseudomonas Flourescens, dan Trichoderma harzianum untuk mengendalikan Ralstonia solanacearum", J. Hor. Vol. 22, No.2, pp. 173180, 2012.

[22] J.T. Hamilton, F.I. Attia, "Effect of mixtures of Bacillus thuringiensis and pesticide on Plutella xylostella and the parasite Thyraella collaris", J. Econ. Entomol. Vol. 70, No.1, pp.146-148, 1977.

[23] S. Kumar, R.E. Masto, L.C. Ram, P. Sarkar, J. George, V.A. Selvi, "Biochar preparation from Parthenium hysterophorus and its potential use in soil Application", Ecological Engineering., Vol. 55, pp. 67- 72. 2013.

[24] Eviati dan Sulaeman, Analisis Kimia Tanah, Tanaman, Air, dan Pupuk. Balai Penelitian Tanah: Balai Besar Litbang Sumber Daya Lahan Pertanian, Badan Penelitian dan Pengembangan Pertanian, Departemen Pertanian, Bogor. 2009

[25] J.M. Vincent. A Manual for the Practical Study of the Root-Nodule Bacteria. 1.B.P. Handbook No. 15., Blackwett, Oxford, 1970.

[26] E. Hartley, L.G. Gemella, and D.F. Herridge, "Lime pelleting inoculated serradella (Ornithopus spp.) increases nodulation and yield", Soil Biology \& Biochemistry, Vol. 36, pp.1289-1294, 2004.

[27] Y. Wei, Y. Zhao, M. Shi, Z. Cao, Q. Lua, T. Yang, Y. Fana, Z. Wei. "Effect of organic acids production and bacterial community on the possible mechanism of phosphorus solubilization during composting with enriched phosphate-solubilizing bacteria inoculation", Bioresource Technology, Vol. 247, pp. 190-199, 2018.

[28] A.E. Berns, H. Philipp, H.D. Narres, P. Burauel, H. Vereecken, W. Tappe. "Effect of gamma-sterilization and autoclaving on soil organic matter structure as studied by solid state NMR, UV and fluorescence spectroscopy", European Journal of Soil Science. Vol. 59, pp. 540-550, 2008.

[29] T. Bisseling, R.C. Van den bos, A. Van kammen, "The effect of ammonium nitrate on the synthesis of nitrogenase and the concentration of leghemoglobin in pea root nodules induced by Rhizobium leguminosarum", Biochimica et Biophysica Acta, Vol. 539, pp.1-11, 1978.

[30] C.H. Cheng, J. Lehmann, M.H. Engelhard, "Natural oxidation of black carbon in soils: changes in molecular form and surface charge along a climosequence", Geochimica et Cosmochimica Acta, Vol. 72, pp. 15981610. 2008.

[31] Y. Yao, B. Gao, M. Zhang, M. Inyang, A.R. Zimmerman, "Effect of biochar amendment on sorption and leaching of nitrate, ammonium, and phosphate in a sandy soil", Chemosphere, Vol. 89, pp. 1467-1471, 2012.

[32] Subba-Rao NS, Biofertilizer in Agriculture. New Delhi (IN): Oxford and IBH Publishing Co, New Delhi, 1982.

[33] N. Fahmi, I. Anas, Y. Setiadi, Ishak, "Pengaruh Metode Sterilisasi Radiasi Sinar Gamma Co-60 dan Autoklaf terhadap Bahan Pembawa, Viabilitas Spora Gigaspora margarita dan Ketersediaan Fe, Mn, dan Zn", Jurnal Tanah dan Iklim, Vol. 41, No. 1, pp. 1-8. 2017. 
[34] L. Hale, M. Luth, D. Crowley, "Biochar characteristics relate to its utility as an alternative soil inoculum carrier to peat and vermiculite", Soil Biology \& Biochemistry, Vol. 81, pp.228-235, 2015.

[35] M.T. Prendergast-Miller, M. Duvall, S.P. Sohi, "Localisation of nitrate in the rhizosphere of biochar-amended soils", Soil Biology \& Biochemistr, Vol. 43, pp. 2243-2246, 2011.

[36] L. Hale, M. Luth, R. Kenney, D. Crowley, "Evaluation of pinewood biochar as a carrier of bacterial strain Enterobacter cloacae UW5 for soil inoculation",. Applied Soil Ecology, Vol. 84 , pp. 192-199, 2014. 